\title{
A MODEL OF ANALYSIS OF THE OCCUPATIONAL SAFETY AND HEALTH SYSTEM IN THE PRODUCTION SYSTEM
}

\author{
Biljana Vranješ*, Mladen Todić \\ Faculty of Mechanical Engineering, University of Banja Luka
}

The occupational safety and health system as an integral part of the organization of work includes a set of technical and organized measures and activities aimed at achieving safety at work, elimination and prevention of hazards/ harmfulness that can cause occupational injuries, occupational and other diseases and the protection of health and working capacity workers. The main goal of occupational safety and health is to reduce the number of accidents, injuries, occupational diseases and work-related illnesses. An efficient way of managing the occupational safety and health system is achieved by defining, monitoring and adjusting the performance indicators through a systemic and process approach. The modern concept of occupational safety implies that every worker sees himself as an active participant in the occupational safety system who can contribute to the achievement of his goals, but also the responsibility for the process of improving occupational safety for everyone in the organization. A model of analysis presented in this research enables workers to express their views on the elements of the occupational safety and health system in their organization. By applying this model, we can analyze the input elements related to the profile of workers that influence the acceptance and adoption of basic rules and occupational safety measures. The results of the analysis can be an important source of information in the process of knowledge management in the occupational safety system through the creation of measures to eliminate organizational and functional deficiencies.

Key words: occupational safety and health system, performance indicators, workers

\section{INTRODUCTION}

Occupational safety and health is an action organized systematically and achieved through the application of occupational safety measures, while allowing normal flow of work processes and functioning of production systems and achieving better economic results. In production systems occupational safety is organized using basic, special and recognized rules in accordance with the general principles of prevention. Occupational safety is the overall system of measures taken in order to prevent and eliminate potential hazards that jeopardize the life and health of workers, that is, to ensure more favourable working conditions [1].

An occupational safety management system implies a certain model of organizational and functional structure. This model integrates responsibilities, procedures, processes, resources and information to perform occupational safety activities. The organizational structures of the occupational safety management shown by the models are:

- vertical or linear management approach,

- horizontal or process management approach, and

- combined or life cycle management approach [2]

In today's conditions of rapid change, which affect working processes in the production systems, and thus organizing and functioning of the occupational safety and health system, an efficient way of managing the occupational safety and health system is the application of performance indicators. These are numerical indicators that provide information to the company management on what happened in the previous period and what the current problems and difficulties are in providing occupational safety and health. Performance indicators serve to measure, monitor and manage a company's results in the field of occupational safety and health, that is, the tools for which the enterprise monitors progress and success in achieving occupational safety and health goals. They can be defined as a powerful tool for insight into the adequacy of occupational safety as part of good management and professional practice to measure the achievement of the vision, strategy and objectives of occupational safety and health.Organisational and managerial aspects affect the human behaviour and finally has an effect on the system performances [3], and especially performance at occupational safety. From the standpoint of the success of an occupational safety and health system in the company, prevention is the prevailing purpose of occupational safety and health performance indicators. The feedback of output perfomance (Figure 1) from the occupational safety and health system is a new entry for the continuous improvement cycle, without which the system can not survive in realistic conditions.

The most obvious indicator of the effectiveness of the occupational safety and health system is the number of injuries, occupational diseases, and work-related illnesses. Many factors can lead to accident or injury in the workplace: human performance [4], low awareness of dangers, stress, the nature of workplace design may make important contributions to the occurrence of injuries at workplaces [5]. These generate losses in the production system. Company losses due to work injuries represent the value of unfulfilled work due to the absence 


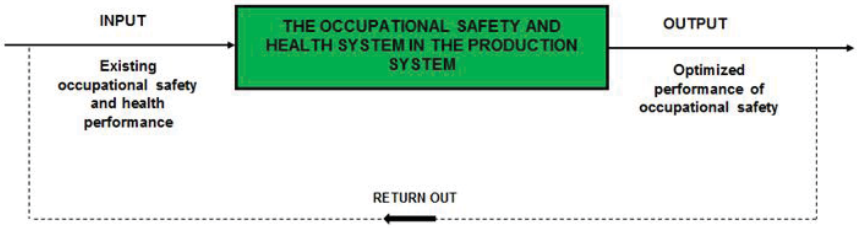

Figure 1: Continuous monitoring of occupational safety and health performance

from work of an injured, ill or other worker, a standstill of means for work and production due to a decline in working morale caused by incurred accidents [6]. These losses are reflected in lost working days, i.e. lost working hours.

The production system in which the research is conducted deals with the production in the field of mining and applies a horizontal process model of the occupational safety and health management system. The effect of occupational safety and health concerned are measured by following these indicators, for which the data are shown in Table 1, and the values obtained in Figure 2:

- injury incidence rate (Ir) [7]:

Injury incidence rate $=\frac{\text { Number of injuries in the analyzed period }}{\text { The average number of workers }}$

- injury frequency rate with lost time (Fr) [8], [9], [10]

$F r=\frac{\text { Number of injuries with lost time }}{\text { Number of working hours }} \cdot 10^{6}$

- injury severity rate with lost time (Sr) [8], [11]

$$
\mathrm{Sr}=\frac{\text { Number of lost working days }}{\text { Number of working hours }} \cdot 10^{3}
$$

The state of occupational safety and health shown in the data in Table 1 indicate that it should be constantly monitored since the goal of reducing the number of injuries or completely eliminating them, achieved in a certain period, did not persist, as there was an increase in the number of injuries and indicators of the state of occupational safety last year. The calculated injury incidence rates and injury frequency rate are shown by the decreasing linear trend model in Figure $2 a$ ) and b), and the value of the injury severity rate by the increasing linear trend model in Figure $2 \mathrm{c}$ ). In shown cases, there are a slight decreasing trend $(b=-0.0182)$ for injury incidence and $(b=-0.0983)$ for the injury frequency rate i.e. growth decreasing trend $(b=0.0075)$ for the injury severity rate. The injury incidence rate has a real meaning if it is derived from a sufficiently large number of cases and observation periods. Criteria are: low $(<2 \%$ of employees injured), moderate (2.1-3\% injured), high (3.1- 6\% injured) and extremely high injury incidence rate $(>6.1 \%$ injured) [7]. Tolerant values for the injury frequency with lost time (Fr) include the numbers between 5 and 10 injuries for every 106 working hours and for a severity $(\mathrm{Sr})$ of 0.5 to 1 for 103 working hours [7]. Keeping these indicators within tolerant limits and stability shows that additional measures of optimization of the existing occupational
Table 1: Data for the calculation of injury indicators for the 2009-2018 period

\begin{tabular}{|c|c|c|c|c|}
\hline Year & $\begin{array}{c}\text { Average } \\
\text { number } \\
\text { of } \\
\text { workers }\end{array}$ & $\begin{array}{c}\text { Number } \\
\text { of } \\
\text { injuries } \\
\text { with lost } \\
\text { time }\end{array}$ & $\begin{array}{c}\text { Number of } \\
\text { lost } \\
\text { working } \\
\text { days }\end{array}$ & $\begin{array}{c}\text { Number } \\
\text { of working } \\
\text { hours }\end{array}$ \\
\hline 2009. & 696 & 5 & 239 & 1171361 \\
\hline 2010. & 705 & 3 & 331 & 1320590 \\
\hline 2011. & 824 & 5 & 216 & 1541360 \\
\hline 2012. & 843 & 1 & 127 & 1565904 \\
\hline 2013. & 854 & 0 & 0 & 1569103 \\
\hline 2014. & 854 & 0 & 0 & 1568943 \\
\hline 2015. & 848 & 1 & 89 & 1555526 \\
\hline 2016. & 813 & 1 & 308 & 1368091 \\
\hline 2017. & 803 & 1 & 263 & 1364028 \\
\hline 2018. & 788 & 7 & 470 & 1364480 \\
\hline
\end{tabular}

safety and health model in the production system are not currently required.

In the production system, all workers must be involved in the process of permanent training and specialization in the field of occupational safety and health. A special activity in the system of occupational safety refers to the process of knowledge management in occupational safety and health. It includes forming and using occupational safety knowledge, in which the process of analyzing performance indicators enables continuous improvement, learning about organizational and functional advantages and disadvantages in the occupational safety and health process, and then acting to eliminate deficiencies.

\section{MATERIAL AND METHODS}

The aim of the research is to present the model of analysis of the occupational safety and health system and its elements, as well as the current state of occupational safety and health in the production system. The analysis will indicate how characteristics of worker's profile (level of educationand total work experience) influence the adoption of principles and rules of occupational safety and active participation in the occupational safety 

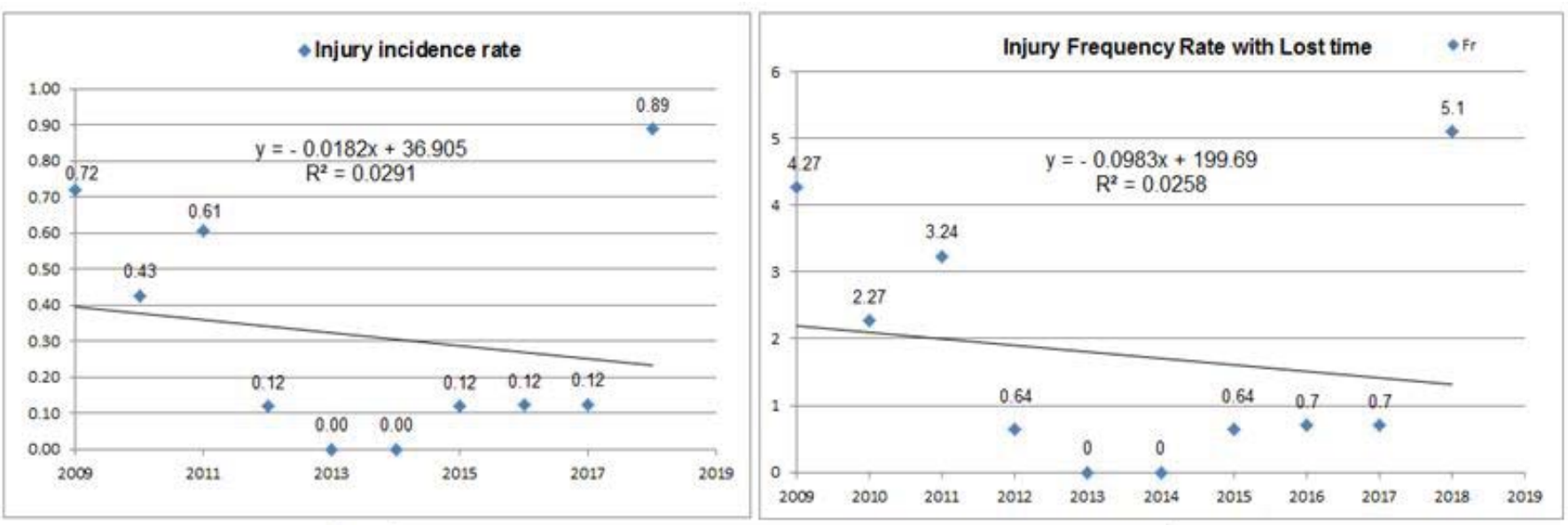

a)

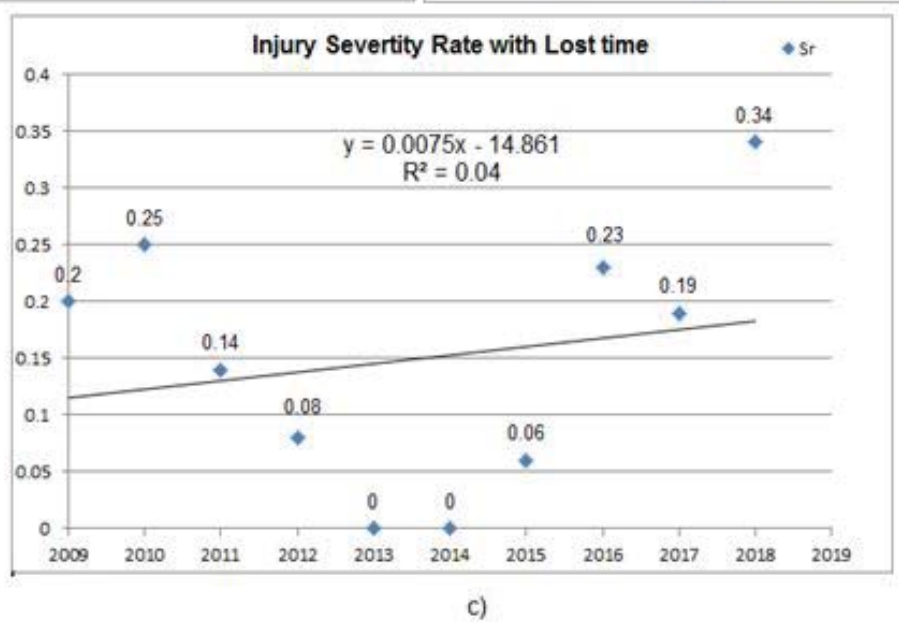

b)

Figure 2: Injury indicators for the 2009-2018 period

system. The analysis will examine the impact of knowledge management of occupational safety on elements of occupational safety and health system. The research aims to prove the hypothesis that there is a connection between the established occupational safety system, knowledge management in the field of occupational safety and the state of occupational safety in the production system.

By examining a representative sample obtained the factual state of the occupational safety and health system was based on worker's subjective opinions (specific and experiential) as direct participants in the system of occupational safety and health. As potential respondents in the research, workers in the production system (mining and processing of mineral raw materials - production of iron ore) were selected, i.e. about 800 potential respondents. The survey involved 300 workers, and was conducted in mid-2018.

A written descriptive-analytical questionnaire was used, which was filled in by workers-respondents in the researcher's presence. The conducted research was voluntary and anonymous for respondents. Survey questions were grouped into four groups based on independent and dependent variables:

1. Independent variables: Worker's profile, The managing knowledge of occupational safety and health in the organization and The occupational safety and health system in the organization

2. Dependent variables: The state (performance) of occupational safety and health in the organization

The questionnaires used are closed type with the offered answers, one which can be selected. Answers to questions in the form of subjective opinions and evaluations of workers/ respondents were used in the Likert scale of intensity of 5 responses: 1 . I totally disagree, 2 . I mostly disagree, 3. I do not know (I neither agree nor disagree), 4. I mostly agree and 5. I totally agree.The variable The state (performance) of occupational safety and health in the organization is graded according to the intensity scale of 3 offered responses.

Descriptive statistics was used for statistical processing of basic data on the profile of the worker-respondent, while analytical statistics was used to respondent's opinion. Statistical statistics was used for statistical analysis: $\mathrm{N}$ - frequency, \% - percentage, $\Sigma$ - sum, M arithmetic mean, $\sigma$ - standard deviation, Md - median, coefficient of correlation (Spearman rho) and correlation matrix, non-parametric test: Kruskal-Wallis-ov $\mathrm{H}$ and verification of the distribution normality (Kolmogorov-Smirnov test). Data were prepared for processing in Microsoft Excel and statistical processing in the IBM SPSS Statistics 23 software package. 


\section{RESULTS AND DISCUSSION}

The sample structure at the frequency level of independent variable Worker's profile is: Gender: men - 251 $(81.7 \%)$ and women $49-(16.3 \%)$; Age: up to 30 years - $30(10 \%)$, from 31 to 40 - $97(32.3 \%)$, from 41 to 50 - 48 (16\%), from 51 to $60-109(36.3 \%)$ and over 60 years 16 (5.3\%); Level of education: high school - 228 (76\%), college - $21(7 \%)$, higher education (graduate engineers) - $49(16.3 \%)$ and masters - $2(0.7 \%)$; Total work experience up to 5 years - $18(6 \%)$, from 6 to $10-83(27.7 \%)$, from 11 to $20-63(21 \%)$, from 21 to $30-22(7.3 \%)$ and over 30 years $-114(38 \%)$

According to descriptive analysis, the mean value of the variable group The occupational safety and health system in the organization (28 individual variables) is more than four (4.09), and the mean value of the variable group The managing knowledge of occupational safety and health in the organization (8 individual variables) is even higher (4.24). The results of the descriptive analysis indicates the workers' satisfaction with the achieved degree of occupational safety and health in their organization, as well as the way of managing knowledge from occupational safety and health. Such high ratings by the workers must not stop the process of continuous monitoring and improvement, as it is an open system subject to impact of internal and external factors that may affect its effectiveness.

Many statistical techniques are based on the assumption about normal distribution of variables, before further data processing, normality check was performed. Kolmogorov-Smirnov's normality test of variance was used to verify normal distribution of variables (Table 2).

The results presented in Table 2 obtained by the Kolmogorov-Smirnov test show the degree of deviation of the obtained results from the normal distribution within individual scales of independent and dependent variables at significance level $p<0.01$. On the basis of these results of deviation from normality it is necessary to transform the research variables (adjustment to the normal distribution), thus non-parametric statistics will be used in further statistical analysis. Results of descriptive statistics of transformed variables whole sample are shown in Table 3.

The highest average value was determined for the variable scale The occupational safety and health system in the organization $(\mathrm{M}=114.42)$, which reflects the function and activities of occupational safety and health for workers.

Table 2: Deviation of distribution of results from normal distribution within selected research variables

\begin{tabular}{|c|c|c|c|c|c|c|}
\hline \multicolumn{7}{|c|}{ Tests of Normality } \\
\hline \multirow{2}{*}{ Production system } & \multicolumn{3}{|c|}{ Kolmogorov-Smirnov ${ }^{a}$} & \multicolumn{3}{|c|}{ Shapiro-Wilk } \\
\hline & Statistic & df & Sig. & Statistic & df & Sig. \\
\hline $\begin{array}{l}\text { 1. The managing knowledge of } \\
\text { occupational safety and health in } \\
\text { the organization }\end{array}$ & .164 & 300 & .000 & .841 & 300 & .000 \\
\hline $\begin{array}{l}\text { 2. The occupational safety and } \\
\text { health system in the organization }\end{array}$ & .127 & 300 & .000 & .910 & 300 & .000 \\
\hline $\begin{array}{l}\text { 3. The state (performance) of occu- } \\
\text { pational safety and health in the } \\
\text { organization }\end{array}$ & .153 & 300 & .000 & .968 & 300 & .000 \\
\hline
\end{tabular}

a. Lilliefors Significance Correction

Table 3: Results of descriptive statistics for transformed research variables

\begin{tabular}{|ll|c|c|c|c|}
\hline \multicolumn{5}{|c|}{ Descriptive Statistics } \\
\hline \multicolumn{1}{|c|}{ Production system } & Min. & Max. & M & $\sigma$ \\
\hline $\begin{array}{l}\text { The managing knowledge of occupational safety and } \\
\text { health in the organization }\end{array}$ & 8 & 40 & 34.01 & 5.644 \\
\hline $\begin{array}{l}\text { 2. } \\
\text { Orge occupational safety and health system in the }\end{array}$ & 43 & 140 & 114.42 & 17.053 \\
\hline $\begin{array}{l}\text { The state (performance) of occupational safety and } \\
\text { health in the organization }\end{array}$ & 8 & 24 & 16.36 & 3.140 \\
\hline \multicolumn{4}{|l|}{ Valid N (listwise) $=300$ cases } \\
\hline
\end{tabular}


To analyze the statistical significance of variations among variables the Worker's profile and the selected research variables, the nonparametric Kruskal Wallis $\mathrm{H}$ test was used to compare the variables with three or more variables on a scale (Tables 4-7).

Table 4: Ranges of the values of variables in relation to the level of education

\begin{tabular}{|c|c|c|c|}
\hline \multicolumn{4}{|c|}{ Ranks } \\
\hline Production system & $\begin{array}{l}\text { Level of } \\
\text { education }\end{array}$ & $\mathrm{N}$ & $\begin{array}{l}\text { Mean } \\
\text { Rank }\end{array}$ \\
\hline \multirow{4}{*}{$\begin{array}{l}\text { 1. The managing } \\
\text { knowledge of } \\
\text { occupational } \\
\text { safety and health } \\
\text { in the } \\
\text { organization }\end{array}$} & High school & 228 & 141.96 \\
\hline & College & 21 & 192.83 \\
\hline & $\begin{array}{c}\text { Higher } \\
\text { education } \\
\text { (graduate } \\
\text { engineers) }\end{array}$ & 49 & 167.96 \\
\hline & Masters & 2 & 251.25 \\
\hline \multirow{4}{*}{$\begin{array}{l}\text { 2. The } \\
\text { occupational } \\
\text { safety and health } \\
\text { system in the } \\
\text { organization }\end{array}$} & High school & 228 & 141.33 \\
\hline & College & 21 & 175.83 \\
\hline & $\begin{array}{l}\text { Higher } \\
\text { education } \\
\text { (graduate } \\
\text { engineers) }\end{array}$ & 49 & 177.71 \\
\hline & Masters & 2 & 262.75 \\
\hline \multirow{4}{*}{$\begin{array}{l}\text { 3. The state } \\
\text { (performance) of } \\
\text { occupational } \\
\text { safety and health } \\
\text { in the } \\
\text { organization }\end{array}$} & High school & 228 & 139.11 \\
\hline & College & 21 & 147.14 \\
\hline & $\begin{array}{c}\text { Higher } \\
\text { education } \\
\text { (graduate } \\
\text { engineers) }\end{array}$ & 49 & 202.57 \\
\hline & Masters & 2 & 208.75 \\
\hline
\end{tabular}

Table 5: Results of the Kruskal Wallis test for research variables: level of education

\begin{tabular}{|c|c|c|c|}
\hline \multicolumn{4}{|c|}{ Test Statistics ${ }^{a, b}$} \\
\hline Production system & 1. & 2. & 3. \\
\hline Chi-Square & 11.991 & 12.517 & 23.024 \\
\hline df & 3 & 3 & 3 \\
\hline Asymp. Sig. & .007 & .006 & .000 \\
\hline \multicolumn{4}{|l|}{ a. Kruskal Wallis Test } \\
\hline \multicolumn{4}{|c|}{ b. Grouping Variable: level of education } \\
\hline \multicolumn{4}{|c|}{ Median } \\
\hline Level of education & 1. & 2. & 3. \\
\hline High school & 35.00 & 116.00 & 16.00 \\
\hline College & 38.00 & 123.00 & 16.00 \\
\hline $\begin{array}{c}\text { Higher education } \\
\text { (graduate engineers) }\end{array}$ & 36.00 & 123.00 & 18.00 \\
\hline Masters & 39.00 & 133.00 & 18.50 \\
\hline Total & 35.00 & 117.50 & 16.00 \\
\hline
\end{tabular}

The results of Kruskal Wallis test (Table 5) showed that there was a statistically significant difference in variables The managing knowledge of occupational safety and health in the organization, The occupational safety and health system in the organization and The state (performance) of occupational safety and health in the organization at a significance level of $<0.01$. Taking into consideration the variables for which statistically significant difference was determined, the workers with the master's degree have the highest statistically significant rank (Table 4) and the median (Table 5). The higher the level of education, the more it affects the adoption of attitudes and norms of behavior that implies a system of occupational safety and health in the production system.

Table 6: Ranges of the value of the variables in relation to the total work experience

\begin{tabular}{|c|c|c|c|}
\hline \multicolumn{4}{|c|}{ Ranks } \\
\hline Production system & $\begin{array}{l}\text { Total work } \\
\text { experience }\end{array}$ & $\mathrm{N}$ & $\begin{array}{l}\text { Mean } \\
\text { Rank }\end{array}$ \\
\hline \multirow{5}{*}{$\begin{array}{l}\text { 1. The managing } \\
\text { knowledge of } \\
\text { occupational } \\
\text { safety and health } \\
\text { in the organization }\end{array}$} & Up 5 years & 18 & 124.22 \\
\hline & $\begin{array}{l}\text { From } 6 \text { to } \\
10 \text { years }\end{array}$ & 83 & 154.90 \\
\hline & $\begin{array}{l}\text { From } 11 \text { to } \\
20 \text { years }\end{array}$ & 63 & 116.10 \\
\hline & $\begin{array}{l}\text { From } 21 \text { to } \\
30 \text { years }\end{array}$ & 22 & 106.70 \\
\hline & $\begin{array}{l}\text { Over } 30 \\
\text { years }\end{array}$ & 114 & 178.91 \\
\hline \multirow{5}{*}{$\begin{array}{l}\text { 2. The occupational } \\
\text { safety and health } \\
\text { system in the } \\
\text { organization }\end{array}$} & Up 5 years & 18 & 141.28 \\
\hline & $\begin{array}{l}\text { From } 6 \text { to } \\
10 \text { years }\end{array}$ & 83 & 150.42 \\
\hline & \begin{tabular}{|l} 
From 11 to \\
20 years \\
\end{tabular} & 63 & 112.71 \\
\hline & $\begin{array}{l}\text { From } 21 \text { to } \\
30 \text { years }\end{array}$ & 22 & 140.27 \\
\hline & $\begin{array}{l}\text { Over } 30 \\
\text { years }\end{array}$ & 114 & 174.87 \\
\hline \multirow{5}{*}{$\begin{array}{l}\text { 3. The state } \\
\text { (performance) } \\
\text { of occupational } \\
\text { safety and health } \\
\text { in the organizatio }\end{array}$} & Up 5 years & 18 & 171.64 \\
\hline & \begin{tabular}{|l|} 
From 6 to \\
10 years \\
\end{tabular} & 83 & 165.08 \\
\hline & $\begin{array}{l}\text { From } 11 \text { to } \\
20 \text { years }\end{array}$ & 63 & 117.77 \\
\hline & $\begin{array}{l}\text { From } 21 \text { to } \\
30 \text { years } \\
\end{array}$ & 22 & 120.91 \\
\hline & $\begin{array}{l}\text { Over } 30 \\
\text { years }\end{array}$ & 114 & 160.35 \\
\hline
\end{tabular}


Table 7: Results of the Kruskal Wallis test for research variables: total work experience

\begin{tabular}{|c|c|c|c|}
\hline \multicolumn{4}{|c|}{ Test Statistics a,b } \\
\hline Production system & 1. & 2. & 3. \\
\hline Chi-Square & 29.860 & 21.477 & 16.776 \\
\hline df & 4 & 4 & 4 \\
\hline Asymp. Sig. & .000 & .000 & .002 \\
\hline \multicolumn{4}{|l|}{ a. Kruskal Wallis Test } \\
\hline \multicolumn{4}{|c|}{ b. Grouping Variable: level of education } \\
\hline \multicolumn{4}{|c|}{ Median } \\
\hline Total work experience & 1. & 2. & 3. \\
\hline Up 5 years & 33.50 & 116.50 & 17.00 \\
\hline From 6 to 10 years & 35.00 & 118.00 & 16.50 \\
\hline From 11 to 20 years & 33.00 & 113.00 & 16.00 \\
\hline From 21 to 30 years & 32.50 & 118.00 & 16.00 \\
\hline Over 30 years & 36.50 & 122.00 & 16.00 \\
\hline Total & 35.00 & 117.50 & 16.00 \\
\hline
\end{tabular}

The results of the Kruskal Wallis test (Table 7) showed that there was a statistically significant difference for all research variables at a significance level of $<0.01$. The variables The managing knowledge of occupational safety and health in the organization and The occupational safety and health system in the organization of workers with over 30 years of work experience have the highest statistically significant ranking (Table 6) and median (Table 7), and the variable The state (performance) of occupational safety and health in the organization for workers with up to 5 years of work experience. The most experienced workers (over 30 years of work experience) are more valued by knowledge management, elements of the system of occupational safety and health, and young workers (with up to 5 years of work experience) other occupational safety and health performance (participation of employees and management in the system of occupational safety and health, mutual dialogue, etc.). Skater diagrams are used to investigate the relationship between variables, most often before calculating correlations. They approximately portray the strength of correlations among variables [12]. Accumulation of points around an imaginary line is indicated a strong correlation. Figure 3 shows that the increase on the scales of The managing knowledge of occupational safety and health in the organization and The occupational safety and health system in the organization is followed by the rise on the scale of The state (performance) of occupational safety and health in the organization (blue line show rise on the scale The state (performance) of occupational safety and health in the organization due to the rise on the scale The managing knowledge of occupational safety and health in the organization; green line show rise on the scale The state (performance) of occupational safety and health in the organization due to the rise on the scale The occupational safety and health system in the organization).

In order to examine whether the presented relationship is statistically significant, a correlation analysis (Spearman's rho) was done. The results of the correlation analysis (Table 8) showed that there is a statistically significant between independent variables and dependent variables of The state (performance) of occupational safety and health in the organization at the significance level of $<0.01$. Workers-respondents who on the scales of The occupational safety and health system in the organization and The managing knowledge of occupational safety and health in the organization higher rated the elements of the occupational safety system and knowledge management on the field of occupational safety, statistically significant, evaluated the state (performance) of occupational safety and health in the organization as good.

Correlation determines the relationship between variables, where as the correlation coefficient determines the strength of that correlation. A strong positive correlation determines the value of the coefficient of 0.5 to 1 [12]. Various interpretations of the correlation coefficient are present in the literature of various authors [13], [14], [15]: from 0.4 to 0.7 is a significant (i.e. moderate) positive, and from 0.7 to 1 high or very high positive correlation. Correlations of individual variables of the groups The managing knowledge of occupational safety and health in the organization are shown in Table 9.

The correlation matrix in Table 8 shows a strong positive correlation between the variables The occupational safety and health system in the organization and The managing knowledge of occupational safety and health in the

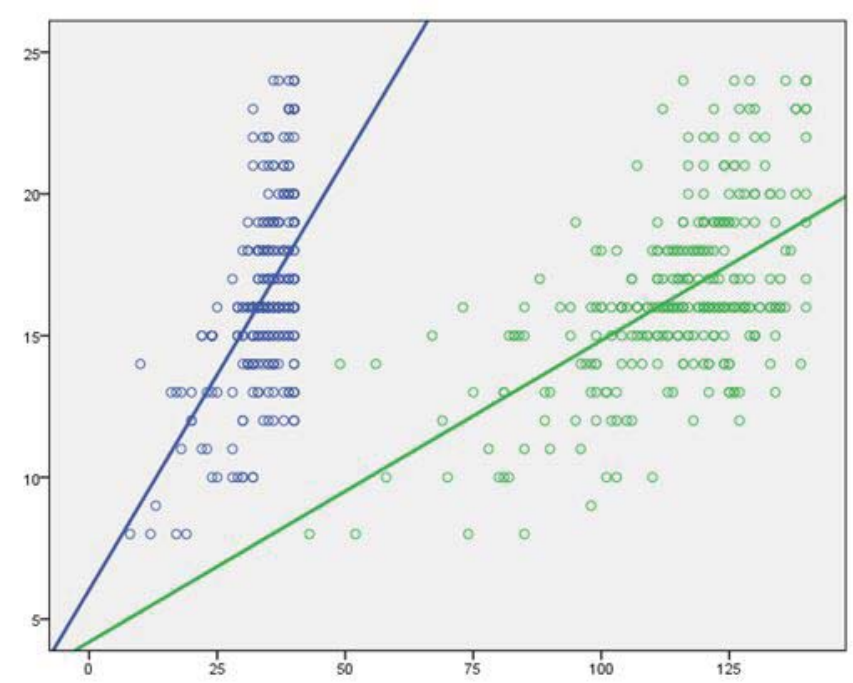

Figure 3: Positive interconnection of independent variables The managing knowledge of occupational safety and health in the organization and The occupational safety and health system in the organization ( $x$-axis) and dependent variables The state (performance) of occupational safety and health in the organization (y-axis) shown by the scattering diagram 
Table 8: Correlation matrix of the relationship of variables

\begin{tabular}{|c|c|c|c|c|c|c|}
\hline \multicolumn{4}{|c|}{ Production system } & 1. & 2. & 3. \\
\hline \multirow{6}{*}{ 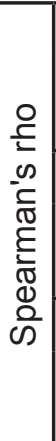 } & \multirow{2}{*}{\multicolumn{2}{|c|}{$\begin{array}{l}\text { 1. The managing knowledge of occupational safety and health } \\
\text { in the organization }\end{array}$}} & Corr. Coeffic. & 1.000 & $.734^{* *}$ & $.473^{\star \star}$ \\
\hline & & & $\begin{array}{c}\text { Sig. } \\
\text { (2-tail.) }\end{array}$ & . & .000 & .000 \\
\hline & \multirow{2}{*}{\multicolumn{2}{|c|}{$\begin{array}{l}\text { 2. The occupational safety and health system in the organiza- } \\
\text { tion }\end{array}$}} & Corr. Coeffic. & $.734^{* *}$ & 1.000 & $.510^{* *}$ \\
\hline & & & $\begin{array}{c}\text { Sig. } \\
\text { (2-tail.) }\end{array}$ & .000 & & .000 \\
\hline & & \multirow{2}{*}{$\begin{array}{l}\text { The state (performance) of occupational safety and health in } \\
\text { the organization }\end{array}$} & Corr. Coeffic. & $.473^{* *}$ & $.510^{* *}$ & 1.000 \\
\hline & & & $\begin{array}{c}\text { Sig. } \\
\text { (2-tail.) }\end{array}$ & .000 & .000 & \\
\hline
\end{tabular}

Table 9: Correlation matrix of variables The managing knowledge of occupational safety and health in the organization

\begin{tabular}{|c|c|c|c|}
\hline \multicolumn{3}{|c|}{ Production system } & \multirow{2}{*}{$\begin{array}{l}\text { The managing knowledge of } \\
\text { occupational safety and health } \\
\text { in the organization } \\
.792^{* *}\end{array}$} \\
\hline \multirow{16}{*}{ 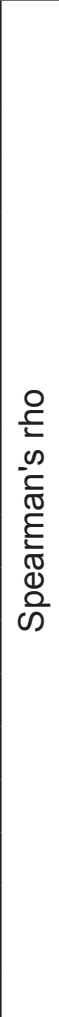 } & \multirow{2}{*}{$\begin{array}{l}\text { Training from occupational safety and health is appropriate } \\
\text { for my work duties }\end{array}$} & Corr. Coeff.. & \\
\hline & & Sig. (2-tail.) & .000 \\
\hline & \multirow{2}{*}{$\begin{array}{l}\text { Workers want and know how to work in a safe manner } \\
\text { respecting the rules of the occupational safety and health }\end{array}$} & Corr. Coeff. & $.597^{* *}$ \\
\hline & & Sig. (2-tail.) & .000 \\
\hline & \multirow{2}{*}{$\begin{array}{l}\text { The organization encourages and organizes further educa- } \\
\text { tion of the workers for acquiring new knowledge from the } \\
\text { occupational safety and health (lectures, trainings, meet- } \\
\text { ings, presentations, seminars, exercises in case of danger, } \\
\text { highlighting good and bad examples) }\end{array}$} & Corr. Coeff. & $.772^{* *}$ \\
\hline & & Sig. (2-tail.) & .000 \\
\hline & \multirow{2}{*}{$\begin{array}{l}\text { Newly employed or transferred workers are effectively } \\
\text { included in the work in a safe manner respecting the rules } \\
\text { of the occupational program }\end{array}$} & Corr. Coeff. & $.703^{* *}$ \\
\hline & & Sig. (2-tail.) & .000 \\
\hline & & Corr. Coeff. & $.703^{\star *}$ \\
\hline & ment is carried out from the occupational safety and health & Sig. (2-tail.) & .000 \\
\hline & \multirow{2}{*}{$\begin{array}{l}\text { Training on how to use tools and equipment for personal } \\
\text { protection }\end{array}$} & Corr. Coeff. & $.761^{\star *}$ \\
\hline & & Sig. (2-tail.) & .000 \\
\hline & \multirow{2}{*}{$\begin{array}{l}\text { Safety rules and instructions are developed and used for } \\
\text { each workplace, i.e. work activity }\end{array}$} & Corr. Coeff. & $.759^{* *}$ \\
\hline & & Sig. (2-tail.) & .000 \\
\hline & \multirow{2}{*}{$\begin{array}{l}\text { Management participates in the education of workers from } \\
\text { the occupational safety and health (tour, attendance of } \\
\text { meetings, presentations, etc.) }\end{array}$} & Corr. Coeff. & $.776^{* *}$ \\
\hline & & Sig. (2-tail.) & .000 \\
\hline
\end{tabular}

organization according to [12], i.e. high positive correlation according to [13], [14], [15]. Between variables The occupational safety and health system in the organization and The state (performance) of occupational safety and health in the organization was determined a strong positive correlation according to [12], i.e. significant (i.e. moderate) positive correlations according to [13], [14], [15]. Between variables The managing knowledge of occupational safety and health in the organization and The state (performance) of occupational safety and health in the organization was determined a significant (i.e. moderate) positive correlations according to [13], [14], [15].
Table 9 shows the established strong positive correlation according to [12], i.e. significant (i.e. moderate) positive (one variable) and high positive correlation according to [13], [14], [15] on all variables The managing knowledge of occupational safety and health in the organization. The highest correlation was determined for the variable Training from occupational safety and health is appropriate for my work duties, from this we can conclude that in the existing managing knowledge in occupational safety and health in the observed production system is considered by workers to have adequate knowledge of occupational safety and health for performing their work 
activities. This variable explains $62.73 \%(0.792 \times 0.792)$ variances in the workers' responses to the scale of The managing knowledge of occupational safety and health in the organization.

Correlations of individual variables of the groups The managing knowledge of occupational safety and health in the organization and variable The occupational safety and health system in the organization are shown in Table 10.

Table 10 shows the established strong positive correlation (except for one variable) according to [12], i.e. significant (i.e. moderate) positive correlation according to [13], [14], [15] for all individual variables of The managing knowledge of occupational safety and health in the organization and variable The occupational safety and health system in the organization. The highest correlation was determined for the variable Management participates in the education of workers from the occupational safety and health (tour, attendance of meetings, presentations, etc.), hence, we can conclude that in the existing system of occupational safety in the observed production system, workers consider that the participation of management in the process of training in the field of high level occupational safety and health. This variable explains $36.48 \%$ (0.604 x 0.604) variances in workers' responses to the scale of The occupational safety and health system in the organization. This result leads to conclusion that the workers consider the active participation of management in the education system on the field of occupational safety and health as important for the functioning of the occupational safety and health system in the production system.

\section{CONCLUSION}

The demonstrated management model of the occupational safety and health system by tracking the indicators is simple to view and analyze the current state of occupational safety and health in the production system, with the possibility of indicating a forward-looking situation in the future by monitoring the line trend of indicators. The egress of performance indicators beyond tolerant frameworks indicates the need to optimize the existing occupational safety and health system and design measures for system correction. The modern approach to occupational safety and health management prefers defining, measuring, monitoring and reviewing performance indicators as the most effective method.

Statistical analysis shows that certain characteristics of the workers' profiles (work experience and level of education) affect the level of evaluation of the occupational

Table 10: Correlation matrix of the relationship of individual variables The managing knowledge of occupational safety and health in the organization and The occupational safety and health system in the organization

\begin{tabular}{|c|c|c|c|c|}
\hline \multicolumn{4}{|c|}{ Production system } & \multirow{2}{*}{$\begin{array}{l}\text { The occupational safety } \\
\text { and health system in the } \\
\text { organization } \\
.568^{* *}\end{array}$} \\
\hline \multirow{16}{*}{ 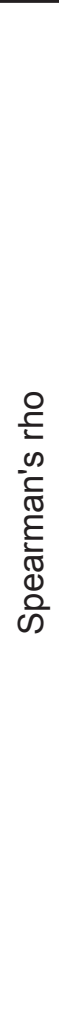 } & \multirow{16}{*}{ 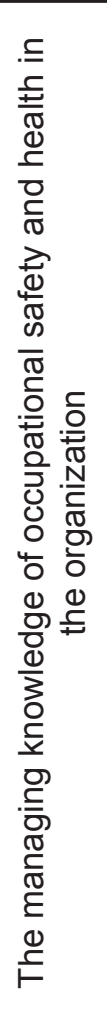 } & \multirow{2}{*}{$\begin{array}{l}\text { Training from occupational safety and health is appropriate } \\
\text { for my work duties }\end{array}$} & Corr. Coeff. & \\
\hline & & & Sig. (2-tail.) & .000 \\
\hline & & \multirow{2}{*}{$\begin{array}{l}\text { Workers want and know how to work in a safe manner re- } \\
\text { specting the rules of the occupational safety and health }\end{array}$} & Corr. Coeff. & $.453^{* *}$ \\
\hline & & & Sig. (2-tail.) & .000 \\
\hline & & \multirow{2}{*}{$\begin{array}{l}\text { The organization encourages and organizes further educa- } \\
\text { tion of the workers for acquiring new knowledge from the } \\
\text { occupational safety and health (lectures, trainings, meet- } \\
\text { ings, presentations, seminars, exercises in case of danger, } \\
\text { highlighting good and bad examples) }\end{array}$} & Corr. Coeff. & $.540^{* *}$ \\
\hline & & & Sig. (2-tail.) & .000 \\
\hline & & \multirow{2}{*}{$\begin{array}{l}\text { Newly employed or transferred workers are effectively } \\
\text { included in the work in a safe manner respecting the rules of } \\
\text { the occupational program }\end{array}$} & Corr.. Coeff. & $.506^{* *}$ \\
\hline & & & Sig. (2-tail.) & .000 \\
\hline & & \multirow{2}{*}{$\begin{array}{l}\text { Training prior to the introduction of a new process or equip- } \\
\text { ment is carried out from the occupational safety and health }\end{array}$} & Corr. Coeff. & $.534^{\star *}$ \\
\hline & & & Sig. (2-tail.) & .000 \\
\hline & & \multirow{2}{*}{$\begin{array}{l}\text { Training on how to use tools and equipment for personal } \\
\text { protection }\end{array}$} & Corr. Coeff. & $.563^{\star *}$ \\
\hline & & & Sig. (2-tail.) & .000 \\
\hline & & \multirow{2}{*}{$\begin{array}{l}\text { Safety rules and instructions are developed and used for } \\
\text { each workplace, i.e. work activity }\end{array}$} & Corr. Coeff. & $.594^{\star *}$ \\
\hline & & & Sig. (2-tail.) & .000 \\
\hline & & \multirow{2}{*}{$\begin{array}{l}\text { Management participates in the education of workers from } \\
\text { the occupational safety and health (tour, attendance of } \\
\text { meetings, presentations, etc.) }\end{array}$} & Corr. Coeff. & $.604^{* \star}$ \\
\hline & & & Sig. (2-tail.) & .000 \\
\hline
\end{tabular}


safety and health system, its elements, knowledge management in occupational safety and health and state of occupational safety and health expressed through the performance indicators.

The managing knowledge of occupational safety and health in the investigated production system wich described through selected individual variables with a determined high level of correlation describe, the current high level of occupational safety knowledge.

The established high level of correlation between the variables that describe the management of knowledge from occupational safety and health and the system of occupational safety and health point to the importance of training and permanent education of workers in achieving the occupational safety and health goals.

\section{REFERENCES}

1. Anđelković, B. (2010).The basics of the protection system. University of Niš, Faculty of occupational safety in Niš, Niš, ISBN 978-86-6093-018-9, COBISS.SR-ID 180624908

2. Knegtering,B. (2002). Safety life cycle management in the process industries: the development of a qualitative safety-related informationan alysis technique. Eindhoven: Technische Universiteit Eindhoven, ISBN 90-386-1747-X

3. Milazzo, F.M. [2016]. On the importance of managerial and organisational variables in the quantitative risk assessment. Journal of Applied Engineering Science, 14(1), 54-60.

4. Wachter, K. J., Yorio, L. P. (2014). A system of safety management practices and worker engagementfor reducing and preventing accidents: An empirical and theoretical investigation. Accident Analysis and Prevention, volume 68 , july 2014 , pages $117-130$, doi. org/10.1016/j.aap.2013.07.029

5. Sun,Y., Arning, M.,Bochmann, F., Börger, J., Heitmann, T. (2018). Development and Validation of a Practical Instrument for Injury Prevention: The Occupational Safety and Health Monitoring and Assessment Tool (OSH-MAT). Safety and Health at Work, Volume 9, Issuse 2, June 2018, pages 140-143, doi. org/10.1016/j.shaw.2017.07.006
6. Spasić, D. (2001). Occupational Safety Economics. Graphic company SVEN, Niš, Serbia

7. Krstić, I. (2010). Models for systemic analysis of technological systems(Doctoral dissertation, Faculty of Occupational Safety in Niš, Niš, Serbia)

8. Venkataraman, N. (2008). Safety Performance Factor. International Journal of Occupational Safety and Ergonomics (JOSE), Vol. 14, No. 3, 327-331, doi.org /10.1080/10803548.2008.11076772

9. Rajaprasad, S. V. S., Chalapathi, P. V. (2016). An analysis of accident trends and modeling of safety indices in an Indian construction organization. Independent Journal of Management \& Production (IJM\&P), v. 7, n. 3, ISSN: 2236-269X,DOI: 10.14807/ ijmp.v7i3.432

10. Živković, S., Pavlović, D. (2014). The comparative analysis of the number of occupational injuries in Serbia, Croatia and Slovenia in 2012. Facta Universitatis, Series: Working and Living Environmental rotection, Vol. 11, No 1, 53 - 64, UDC 517:614.8.027, ISSN 2406-0534

11. Stranks, J. (2002). Health and safety at Work: Key Terms, Butterworth-Heinemann, Oxford, Great Britain, ISBN 0750654465

12. Pallant, J. (2007). SPSS Survival Manual: A Step by Step Guide to Data Analysis Using SPSS for Windows (Version 15), Allen \& Unwin

13. Petz, B. (1997). Basic statistical methods for non-mathematicians, Edition Waterfall, Zagreb, Croatia, UDK 311(075.8), ISBN 978-953-191-058-3

14. Asuero, G. A., Sayago, A., Gonz'alez, G. A. (2006). The Correlation Coefficient: An Overview. Critical Reviews in Analytical Chemistry, 36:41-59, 2006, Copyright (C) Taylor and Francis Group, LLC, ISSN: $1040-8347$, print / 1547-6510 online, DOI: 10.1080/10408340500526766

15. Ratner, B. (2009). The correlation coefficient: Its values range between $+1 /-1$, or do they ?.Journal of Targeting, Measurement and Analysis for Marketing,Vol. 17, 2, 139-142, doi: 10.1057/jt.2009.5

Paper submitted: 16.04.2019.

Paper accepted: 06.06.2019.

This is an open access article distributed under the CC BY-NC-ND 4.0 terms and conditions. 